\title{
Governance and Performance in Insurance Companies: A Bibliometric Analysis and A Meta-Analysis
}

\author{
Luisa Anderloni ${ }^{1}$, Ornella Moro ${ }^{2} \&$ Alessandra Tanda ${ }^{3}$ \\ ${ }^{1}$ Department of Law “Cesare Beccaria”, Università degli Studi di Milano, Italy \\ ${ }^{2}$ Dipartimento di Scienze Economiche e Aziendali, Università degli Studi di Sassari, Italy \\ ${ }^{3}$ Department of Economics and Management, University of Pavia, Italy \\ Correspondence: Alessandra Tanda, Department of Economics and Management, University of Pavia, via San \\ Felice, 5 - 27100 Pavia, Italy. E-mail: alessandra.tanda@ unipv.it
}

Received: August 8, 2020

Accepted: September 29, 2020

Online Published: October 5, 2020

doi:10.5539/ijef.v12n11p1

URL: https://doi.org/10.5539/ijef.v12n11p1

\begin{abstract}
This paper provides a review of theoretical contributions and empirical studies on the external and internal mechanisms of corporate governance of insurance companies and their effects on performance and/or risk. Thanks to the analysis of the studies published between 1985 and 2019 through bibliometric tools, we are able to illustrate the networks of scientific collaborations (co-authorship) and relationships between the most used terms, also highlighting the most significant groups of scholars and research strands. Additionally, the paper carries out a meta-analysis of around thirty quantitative articles that show a relationship between the quantitative-qualitative characteristics of the Board of Directors and the performance of the insurance company. The empirical studies show a consensus on the positive contribution of board size and the presence of independent directors on performance. Moreover, insurance research networks do not appear to be very interconnected, especially as regards to emerging markets. The paper also provides a useful starting point for future research aimed at defining the specificities of the governance-performance relationship of insurance companies within an evolving regulatory and market framework.
\end{abstract}

Keywords: corporate governance, insurance, meta-analysis, performance, bibliometric review

JEL: G30, G22, M21.

\section{Introduction}

The structure and operation of corporate governance systems have always been of great importance in business management and received much attention by the literature. Nevertheless, recently the issue gained a renewed interest. In fact, the quality of the system of governance is of special interest not only for financial intermediaries, but also for institutional investors and markets, that operate their own assessments, combining classic fundamental analyses of a company with considerations linked to organizational and management aspects, among which governance has a key role.

Indeed, the set of processes, mechanisms, organizational structures and their inter-connections through which companies are controlled and managed is part of both the due diligence evaluation process for complex financial transactions, and of the Environmental, Social, Governance (ESG) evaluation to which the market, understood in a broad sense, is paying increasing attention.

Furthermore, in the recent process of redrawing prudential banking legislation, it has been important to define an apparatus of rules aimed precisely at strengthening the governance of financial intermediaries, providing for requirements that individual directors and the board in its entirety must respect with regard to competence, diversity and commitment to the board (see Locatelli, Schena, Tanda, \& Uselli, 2018).

A large part of the financial and economic literature has been devoted to this theme, both from a theoretical and empirical points of view. This has led to several - and very rich - strands of literature.

Among the governance studies, most empirical analyses are intra-sectoral, i.e. they analyse the company's governance systems without considering the sampled companies' sectors or, in some cases, they deal with the financial sector as a whole (which merits separate treatment as the "special" or supervised financial 
intermediaries may have different governance mechanisms capable of producing the desired effects of a good governance system). The insurance sector is one of these "special" industries which deserves specific focus.

The aim of this study is to examine the literature and empirical research on governance in the insurance industry with a traditional review and through the help of the bibliometric tools, and then focus, through a meta-analysis, on the relationship between governance solutions and the economic performance of insurance companies.

The following paragraph presents the theoretical assumptions of governance models and empirical evidence with specific reference to the insurance sector, with a view to identifying the main research issues, studies and evidence. In paragraph 3, the results of a bibliometric analysis of research networks on governance in the insurance industry are presented, while paragraph 4 presents the results of a meta-analysis on the relationship between governance and performance. The last paragraph discusses the results and identifies possible further streams of research that merit attention.

\section{Theoretical Assumptions and Empirical Evidence}

According to the Agency Theory potential conflicts of interest arise in companies where ownership and control are split, due to the different objectives of the main players: ownership (principal) and management (agents). The former have a medium/long-term time horizon and their objective is to optimize the risk/return of their investment over that time frame. Managers have a shorter time horizon, linked to the permanence of their office. They aim to maximizing the value of the company in that time frame and are therefore willing to accept higher levels of risk (Boubakri, Dionne, \& Triki, 2008; Fama \& Jensen, 1983).

Some corporate governance mechanisms have been identified by the literature as a solution to reduce conflicts between principals and agents, allowing shareholders to exercise effective control over management to protect their own interests or to align the objectives of shareholders and managers more closely.

Studies on governance dedicated to insurance companies are less common than cross-sector studies or studies focusing on the banking and finance sector (taken as a whole). The fewer studies on insurance companies are published in specialist journals and when conducted in non-Anglo-Saxon countries, they are characterized by smaller survey samples (Fekadu, 2015; Garba \& Abubakar, 2014; Gugong, Arugu, \& Dandago, 2014; Hidayat \& Firmansyah, 2017; Ibe, Okanya, \& Ogochukwu, 2017; Jeng \& Lai, 2005; Kader, Adams, \& Hardwick, 2010; Lee, Cheng, Har, Md Nassir, \& Ab Razak, 2019; Li, Zhang, Tsai, \& Qiu, 2017; Najjar \& Salman, 2013; Sandada, Man-zanga, \& Shamhuyenhanzva, 2015; Wang, Jeng, \& Peng, 2007). Studies in developed countries concern almost exclusively the United States, the United Kingdom (Hardwick \& Letza, 1999, 2003; O'Sullivan \& Diacon, 1999, 2003) and only a few other European countries (Deev \& Khazalia, 2017; Eling \& Marek, 2014; Genetay, 1999; Lambalk \& de Graaf, 2017; Pavi Kramari, Aleksic, \& Pejic-Bach, 2018; Pullano, 2011; Venuti \& Alfiero, 2016). More recently, the research has been extended to companies following Islamic precepts (Fekadu, 2015; Kader et al., 2010; Kader, Adams, Hardwick, \& Kwon, 2014; Karbhari, Muye, Hassan, \& Elnahass, 2018; Lee et al., 2019; Markonah, Sudiro, \& Rahayu, 2019; Najjar \& Salman, 2013; Ng, Chong, \& Ismail, 2012)

However, a focus on insurance research on governance contributes to enriching the results of the wider research strand with thanks to the specific features of the insurance companies.

The motivations that led scholars to delve into the governance issues in the insurance field are different:

1) Focusing on a single sector excludes the influence on the results of factors specific to other industries, whether regulatory, economic or other (Diacon \& O'Sullivan, 1995, Adams \& Jiang, 2017b). For example, insurance regulatory oversight implements an external validation and monitoring process (and sometimes exert conditioning) of many governance choices that would not apply to industries and would be different in other financial intermediaries;

2) The availability of detailed data thanks to the disclosure, imposed by industry legislation, of a large set of information of a technical-accounting nature, enables comparisons based on specific indicators (Lambalk \& de Graaf, 2017);

3) The large number of insurance company stakeholders - policyholders, damaged third parties, reinsurers (Doherty \& Dionne, 1993; Lamm-Tennant \& Starks, 1993), as well as supervisors and shareholders - implies a strong focus on good governance. This contributes to influencing management, both in terms of disclosure of information on the company's performance (Adams \& Hossain, 1998) and for decisions as regards risk and solvency (Cole, He, McCullough, Semykina, \& Sommer, 2011; Deev \& Khazalia, 2017);

4) In the insurance sector there is a wide range of proprietary structures (Hardwick \& Letza, 1999; Mayers \& Smith, 1988). It is possible, therefore, to make comparisons on the effectiveness of governance mechanisms 
between different types of companies, or to focus on companies belonging to a single class (mutuals, or, among the stock companies, those controlled by specific shareholders: institutional investors, managers, savers, other companies) to more accurately define the relationship between the governance tool investigated and the dependent variable studied (Mayers \& Smith, 2010). In the insurance field there are many cases of "business groups", so that this aspect is considered by some researchers to better analyze the independence of outside directors, the breadth of power of the CEO, the role played by some committees (Diacon \& O'Sullivan 1995; He \& Sommer 2010) and also management incentive tools (Mayers \& Smith, 1992);

5) In the same sector, it is then possible to carry out in-depth analyses on certain types of enterprises (defined according to "production" aspects), in order to more accurately isolate the effects of certain governance choices in a homogeneous sample. The areas of investigation can cover both life and non-life companies or companies specializing in only one of the two sectors. They could be in turn multi-risk companies or companies specialising only in certain class of risk or business (e.g. assistance, accidents and illnesses, credits, civil liability). The implications, in terms of what governance tools to use and how effective they are vary depending on the sector (life or non-life) and the specific class of business or on the risk level ("short tail" or "long tail"). In non-life, there is a time horizon of a few years, except for long tail risks that have a potential long queue of claims, a wider variability of risks and greater difficulty in forecasting. Consequently, in such companies, there is generally greater discretion and risk in strategic and management decisions, greater CEO power, as well as different skills required for decision-making bodies and internal board committees (Adams \& Jiang, 2017b; Diacon \& O'Sullivan, 1995). It is therefore possible to define the field of investigation according to the ownership structure, on the one hand, and the production specialization, on the other hand, and still have sufficiently populated and representative samples both in the life (Cheng, Elyasiani, \& Jia, 2011; Connelly, 2004; Hardwick \& Letza, 1999; Mayers \& Smith, 1992; O'Sullivan \& Diacon, 2003) and in any of non-life risk class (Adams \& Jiang, 2017b; He \& Sommer, 2011; Ho, Lai, \& Lee, 2013; Hsu, Huang, \& Lai, 2015; Lambalk \& de Graaf, 2017; Miller, 2011);

6) The extreme complexity of the insurance business requires specialist skills of various kinds (legal, actuarial, technical and financial) as well as knowledge of business, regulation and specific experience (Adams \& Jiang, 2017b; Hardwick, Adams, \& Zou, 2011). The focus of studies on this area allows to see, more than in other areas, whether and how much the quality characteristics of the Board and the CEO affect the effectiveness of governance.

Apart from the theoretical or literature review studies (Bansal \& Bansal, 2014; Boubakri, 2011; Hansmann, 1985; MacMinn \& Ren, 2010), empirical research on corporate governance in the insurance industry can be split into various lines of research with multiple intersections: a first area is the relationship between ownership status and effectiveness of governance. Studies focus on the distinction between mutuals and equity-capital enterprises (Boubakri, 2011; Cole, He, McCullough, \& Sommer, 2011; Diacon \& O'Sullivan, 1995; Diacon, O’Brien, Drake, \& O'Sullivan, 2005; Hardwick et al., 2011; He \& Sommer, 2010; Ho et al., 2013; Mayers, Shivdasani, \& Smith, 1997; Mayers \& Smith, 1994; O'Sullivan \& Diacon, 2003). They focus on single types, for example mutuals alone (Mayers \& Smith, 2010) or, within the stock companies, on increasingly detailed classifications, related to the strength of shareholders' control, the nature of the shareholders, the role of institutional investors, the management's holding in equity (Barrese, Lai, \& Scordis, 2005; Cole, He, McCullough, Semykina, et al., 2011; He, Sommer, \& Xie, 2011; Ho, Lai, \& Lee, 2009) or, finally, the type of parent companies (Diacon \& O'Sullivan, 1995; O'Sullivan \& Diacon, 1999). Some contributions limit the study to listed companies only (Miller, 2011).

In this area of study (but also more generally), the effectiveness of governance is assessed mainly in terms of financial performance or risk measures.

Financial performance is studied as a market performance, often translated by Tobin's Q indicators (Barrese et al., 2005; Cheng et al., 2011; Deev \& Khazalia, 2017; Miller \& Yang, 2015) or by the ratio of market capitalization to book value (Hsu et al., 2015) or as a performance measured on accounting data, expressed by ROE and/or ROA (Adams \& Jiang, 2016; He \& Sommer, 2010; He et al., 2011). In many studies, performance is assessed in terms of efficiency (Hardwick, Adams, \& Zou, 2003; Hsu \& Petchsakulwong, 2010; Huang, Lai, McNamara, \& Wang, 2011; Huang et al., 2011; Kader et al., 2010; Lee et al., 2019), as revenue-side efficiency or cost-side efficiency, technological efficiency or allocative efficiency.

Risk is also expressed in terms of variability of accounting (variability of ROE or ROA (Ho et al., 2013)) or market performance (Cheng et al., 2011; Elamer, AlHares, Ntim, \& Benyazid, 2018; Magee, Schilling, \& Sheedy, 2019). Otherwise it can be interpreted as underwriting risk (Ho et al., 2009; $\mathrm{Ng}$ et al., 2012) or, also, measures of financial risk, risk of underestimating technical reserves and investment risk (Eling \& Marek, 2014; Ho et al., 
2013; Lambalk \& de Graaf, 2017; Li et al., 2017).

In the following streams of research, often also defined on the basis of a specific insurance sector (non-life, life or both), scholars sought to understand which governance mechanisms are most effective for achieving the objectives: these studies focus on the figure and power of the CEO (Adams \& Jiang, 2017a; He \& Sommer, 2011), the composition and characteristics of the board (Hardwick et al., 2011), the role of independent directors, the role of the internal board committees, the types of incentives.

Finally, some studies consider the likelihood of turnover of the CEO or the entire board ( Xie, Cai, Lu, Liu, \& and Takumi, 2016; He \& Sommer, 2011), incentives to manipulate performance to increase management's variable remuneration (Eckles, Halek, He, Sommer, \& Zhang, 2011) and also the risk branch choices within the Managerial Discretion Hypothesis (Mayers \& Smith, 1988, 1994; Miller, 2011).

Governance tools are generally distinguished into external and internal tools (Table 1). External governance mechanisms are market mechanisms and the threat of takeovers, the action of external stakeholders other than shareholders, the managerial labor market, which co-opts the best CEOs or outside directors. Internal governance mechanisms include the quantitative and qualitative characteristics of the Board, the breadth of the CEO's power and his/her characteristics, the presence and characteristics of the internal board committees, the tools of incentive and management remuneration (CEO, Board, management), financial policies (debt and dividend distribution).

The taxonomy proposal is referenced below for a literature review of the empirical studies focused on governance tools used in insurance companies and their impact on performance in the many possible configurations mentioned above.

Table 1. Summary of governance mechanisms

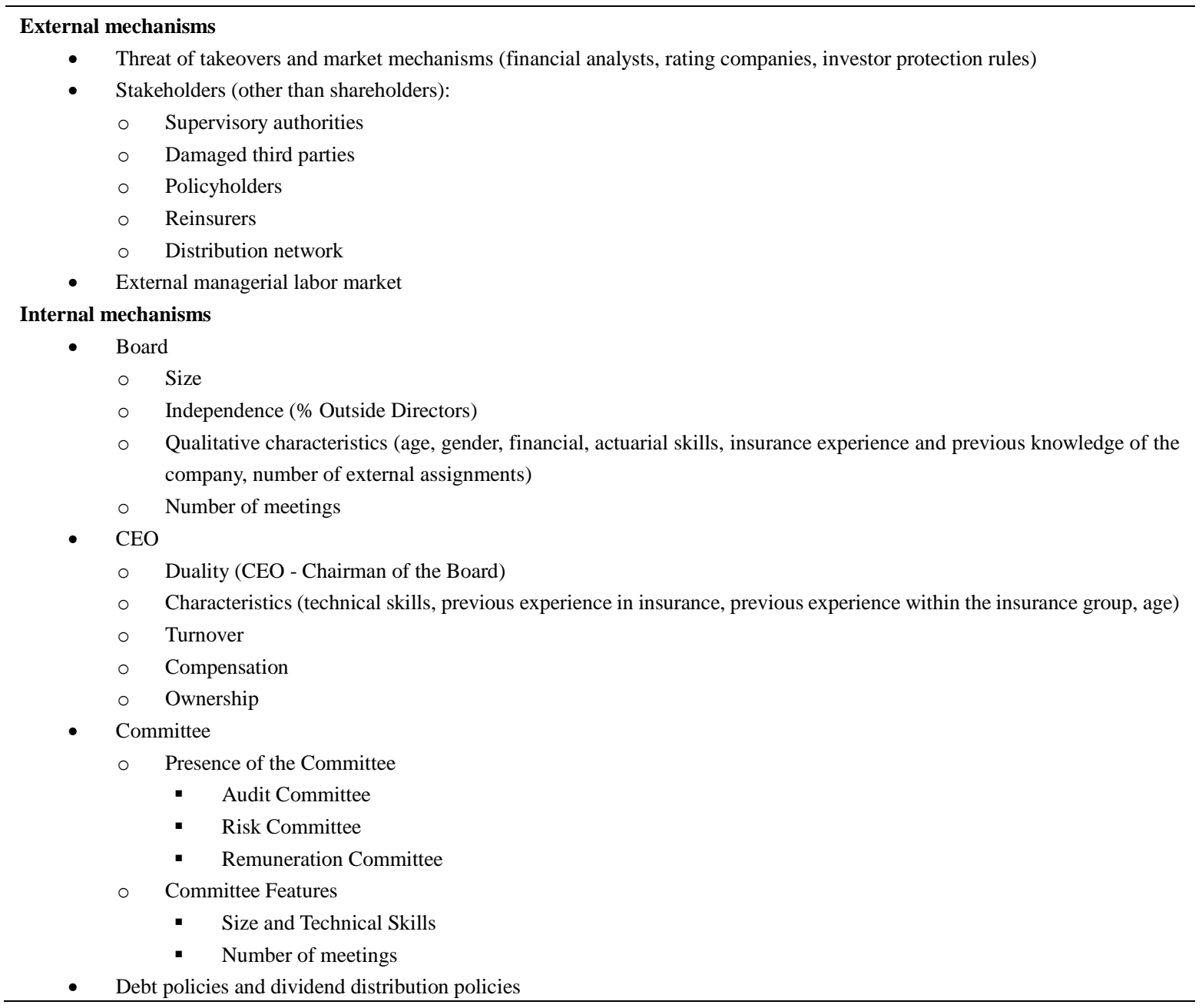




\subsection{External Mechanisms}

\section{Takeovers and market mechanisms}

Takeovers are market mechanisms and they hence do not apply to mutuals or unlisted companies. Moreover, even if one considers only the listed companies, the possibility of a real takeover depends on the characteristics of the shareholders, in terms of shares held (widespread shareholding, presence of blocks of shareholders, majority-controlled companies, publicly controlled companies), on the degree of liquidity of the listed shares and on the efficient functioning of the stock market, and, finally, on regulatory rules and/or on the state's action in the hypothesis of public ownership. Among the market mechanisms for listed companies, financial analysts and rating companies that provide studies and judgments might affect the share price and, indirectly, the work of management. This also applies to the rules of investor protection and, more broadly, the legal system of a country. In the insurance industry, numerous studies show that the lack of some external control tools (e.g. for mutual) conditions decisions relating to other instruments, in terms, for example, of the size and degree of independence of the board, as well as the power assigned to the CEO (Boubakri et al., 2006; Diacon, O'Brien, Drake, \& O'Sullivan, 2004; He \& Sommer, 2010; Mayers et al., 1997).

\section{External stakeholders}

Governance studies relating to the insurance field alone include, among the external mechanisms, industry-specific regulation and close monitoring by supervisors: both affect the management of the company and intervene to delimit the potential conflicts between the various stakeholders, not only between shareholders and managers but also between shareholders and policyholders or damaged third parties (Li et al., 2017). Some studies also include the monitoring carried out by reinsurance companies (Boubakri et al., 2006; Cole et al., 2011), similar to what is observed in the relationships between banks on the interbank market. Others point out that the distribution networks themselves can exert external control over the work of management. In this regard, one can think of the attention that banking networks, as distributors of life insurance policies, place on the solvency of the issuer and how they worry that there are no conflicts of interest between the company's shareholders and their customers/insured, for example in terms of allocation of investment income, low claims settlements in order not to compromise profits (Cole et al., 2011).

\section{External managerial labor market}

Another external governance tool is the "managerial job market" (He \& Sommer, 2010): reputation, number of assignments and experience help define the degree of "appeal" of CEOs, especially if they are appointed without internal career paths. This also applies to independent directors (outsiders) who aspire to have a reputation as "effective controllers" so as to enrich their curriculum for future assignments.

\subsection{Internal Mechanisms}

The internal mechanisms relate to the Board of Directors (or boards) (both quantitatively and qualitatively), the figures of the CEO and Chairman of the Board, the Audit Committee and the possible presence of other Committees (Risk Committee and/or Remuneration Committee), management's incentive and remuneration policies, debt and overtime dividend distribution policies.

Empirical studies in the field of insurance investigate a wide variety of combinations of internal governance mechanisms although the size of the board and the cumulation of functions attributed to the same person (as CEO and Chairman) are more frequently employed as explanatory variables. Of the collective bodies, councils and committees, the various studies considered both quantitative and qualitative aspects, including the degree of commitment expressed by the number of meetings in a year.

\section{Board: Board size}

Quantitative aspects relate to the number of components (Board Size) and produce conflicting evidence on governance effectiveness: for some, large boards allow a more effective amalgamation of opinions, experiences, skills, contacts and thus have a positive relationship with the variable surveyed (performance or risk control) (Deev \& Khazalia, 2017), for others, the sign is negative because as the size of the organs increases, coordination becomes more difficult and this, in fact, increases the power of the CEO (Wang et al., 2007) or, for others, there is no relation to performance (Connelly, 2004; Hardwick et al., 2003) or the result is unclear. More granular analyses, for example, which distinguish between cost efficiency and revenue efficiency, show that the board size can be positive on the cost control side (Hardwick et al., 2011; Hsu \& Petchsakulwong, 2010; Huang et al., 2011) and negative on the revenue maximization side (Hsu \& Petchsakulwong, 2010).

\section{Board: Outside directors}


As regards the quality of the Board, the most investigated feature is independence of judgment and monitoring on the CEO's work. The variable is typically expressed in terms of the number or percentage of outside directors within the board. Outside directors are also referred to as "independent directors" or "non-executive directors". What they have in common is that they are not exposed to the influence of shareholders, management or other parties (Hsu \& Petchsakulwong, 2010), they have no business or consultancy ties with the company or shareholders, they have no family ties (usually examined by the similarity of the surname) with shareholders and management (He \& Sommer, 2010). The presence of outside directors increase the effectiveness of governance because the motivation to enhance their reputation as independent, and thus their value on the "external job market" precludes collusive behavior with management (Hardwick et al., 2011; Lin, Pope, \& Young, 2003). Their action is positively reflected in performance (Connelly, 2004) and promotes risk reduction (Eling \& Marek, 2014; Ho et al., 2013). However, the degree of independence may vary over time in relation to the length of time spent on the Board and the consequent greater familiarity between directors and management, or may be called into question by previous appointments to group companies (Adams \& Jiang, 2016; O'Sullivan \& Diacon, 1999) or other bodies of the company, such as the Audit Committee (He \& Sommer, 2010).

The presence and number of outside directors, regardless of any regulatory constraints, is often related to the intensity of potential conflicts of interest between principals and agents. There are numerous studies on ownership, mutual or company assets (and within this with disaggregation into various possible categories) that highlight the different use of outside directors in relation to the intensity of shareholder' control over management's work. In the case of poor control, as in the case of mutuals, there is widespread use of outside directors (He \& Sommer, 2010; Mayers et al., 1997). On the other hand, in the case of strong control by the majority shareholder, for example in the case of companies belonging to an insurance group, the number of outside directors is much lower (O'Sullivan \& Diacon, 1999), probably also due to the mutual control exercised between the top managers of the group companies (He \& Sommer, 2010) and the presence of the latter mainly responds to the need to obtain competences outside the company.

The empirical evidence on the effectiveness of governance in relation to outside directors does not concur: for some the relationship with performance is positive (Connelly, 2004; Deev \& Khazalia, 2017; Hsu \& Petchsakulwong, 2010), for others it is negative (Deev \& Khazalia, 2017; Eling \& Marek, 2014), others argue that it is negative because it is more important than the action carried out by insiders (Huang et al., 2011); for some still there are no significant relationships (Adams \& Jiang, 2016; Barrese et al., 2005), while according to other authors, finally, it is not so much the presence but the characteristics of the outsiders that determines the relationship (Hardwick et al., 2011). In terms of risk, the report is mostly negative, as outside directors show a lower risk appetite for insiders and the CEO himself (Deev \& Khazalia, 2017; Eling \& Marek, 2014).

\section{Board: Quality Aspects}

Some studies take into account some qualitative aspects of the board as a whole, in terms of age, gender, financial and actuarial skills, as well as in terms of experience in insurance or prior knowledge of the company (Ho et al., 2009; O'Sullivan \& Diacon, 1999). Most studies focus mainly on the characteristics of the outside directors alone (Adams \& Jiang, 2016), as bearers of skills and experience that cannot be found within the company, and for them some articles have also considered the business, political or social connections (Wu, Kweh, Lu, \& Azizan, 2016). Some studies also consider the availability of time to carry out the task, hiring as a proxy to determine the number of assignments (Huang et al., 2011) that, while on the one hand increase the experience and benefits of a potential network (Hsu et al., 2015), on the other hand reduce the time and contribution of the director, so these factors correlate negatively with performance (Adams \& Jiang, 2016).

Another internal governance variable used in the literature is the number of meetings carried out by the board. This variable is also taken into account in the case of the Audit Committee or the Risk Management Committee (Hsu \& Petchsakulwong, 2010; $\mathrm{Ng}$ et al., 2012) and assumed to favor exchange of information within the board/committee and greater involvement of the members. In this regard, the results show that the relationship with performance or efficiency is positive in the case of the Board of Directors (Deev \& Khazalia, 2017), negative in the case of the Audit Committee (Hsu \& Petchsakulwong, 2010) or Risk Management Committee (Wu et al., 2016) while it is positive with risk control (Elamer et al., 2018; Eling \& Marek, 2014).

\section{The CEO}

Another important internal governance tool is the CEO, of which the literature investigates many aspects: from the breadth of the role, to the quality characteristics, the duration of the appointment and the likelihood of replacement in relation to performance or as a result of M\&A operations. 
When the CEO also takes the position of chairman of the board, this results in the centralization of a great amount of information and greater power for a single person, primus inter pares, both for power over the appointments of the internal and external board members (Adams \& Jiang, 2016; Miller \& Yang, 2015), and greater decision powers with less debate within the collegiate body (Hardwick et al., 2011). The separation of roles allows the conflicts of interest between Principal and Agents to be more balanced and it should help to improve performance. However, expanding the CEO's role can be useful when circumstances require speed in decision-making and a highly centralized system of strategic management, or when the decision-making debates tend to be greatly reduced at the boards of group subsidiaries belonging to an insurance group. The empirical findings are somewhat controversial, perhaps due to increased interactions with other instruments, such as the presence of the Audit Committee and the degree of board independence (Hardwick et al., 2011). Some point to a positive relationship with operational efficiency (Diacon \& O'Sullivan, 1995), others find a negative relationship (Adams \& Jiang, 2017a); additional evidence shows no relationship if the company is a subsidiary within an insurance group (Mayers \& Smith, 2010), others exhibit a positive relationship with performance, but only in the case of large companies; otherwise they show that it is not harmful to the company's results (Miller \& Yang, 2015). Part of the literature, on the other hand, show a positive correlation between the cumulation of offices and the assumption of higher levels of leverage risk (Ho et al., 2013). It should be noted, however, that, in some cases, duality of role depends on contingent factors such as the replacement times of the board itself. Only a few authors (Miller \& Yang, 2015) take these circumstances into account in their analysis.

\section{CEO: Quality aspects}

Qualitative aspects are in part similar to those considered for the board members (specifically, for the outside directors) in the insurance industry, i.e. past experience in insurance activities, technical skills, previous experience, and age (Adams \& Jiang, 2017a; Boubakri et al., 2006, Miller \& Yang, 2015; O’Sullivan \& Diacon, 1999).

\section{CEO: turnover}

One aspect of specific investigations is also the CEO turnover, which appears to be inversely related with performance (Boubakri, 2011), i.e. CEOs are frequently replaced in the face of performance deemed unsatisfactory by shareholders. In the insurance field, the few researchers who have specifically addressed these issues have found a positive relationship (Cai et al., 2009; He \& Sommer, 2011; He et al., 2011).

\section{CEO: compensation and ownership}

A stream of research in this field of study also focuses on management remuneration. Some consider remuneration in general terms (executive compensation or management compensation) without further specifying the recipients (Eckles et al., 2011; Eling \& Marek, 2014; Marx, Mayers, \& Smith, 2001; Mayers \& Smith, 2010), others restrict analysis to the board (Hsu et al., 2015; Hsu \& Petchsakulwong, 2010) or, more frequently, to the sole figure of the CEO (Adams \& Jiang, 2017b; Mayers \& Smith, 2010).

Incentive schemes are proven to be effective in driving the company towards its objectives, whether they are performance improvement or risk reduction. Often, these programs include also equity bonuses to reduce potential conflicts of interest between principal and agent (Adams \& Jiang, 2017a) in terms of business value and extended management's time horizon. The equity held by the managers and the CEO, in particular, results positively related with the performance (Boubakri et al., 2006). However, compensation plans with equity bonuses can be adopted only in listed companies: due to the high presence of unlisted companies, this tool is unusable. Furthermore, where the share of managers' ownership reaches significant levels, the issue is considered no longer a question of incentive schemes and the studies on this topic isolate share ownership of managers as a specific category of shareholders.

\section{Committees}

In addition to characteristics of the board and of the CEO and Chairman, a number of studies is focused also on the Committees, among which the Audit Committee stands out. The latter, which is responsible for monitoring the fairness of the Board's decisions, acts to strengthen the independence of external advisers by providing opinions on operational issues and regulatory and fiscal matters. It also makes a judgment on the correctness of the financial reporting to the public (O'Sullivan \& Diacon, 2003), on the adequacy of the provisions of the technical reserves (Adams \& Jiang, 2017b) and also links with the internal auditors (Note 1). The presence and effectiveness of the Audit Committee's action can counterbalance elements of potential weakness in governance, such as poor outside directors' influence and/or the centralization of powers under the CEO, or such as the reduced CEO's experience in the field of insurance (Adams \& Jiang, 2017a), positively affecting performance 
(Adams \& Jiang, 2016; Hardwick et al., 2011). Other researchers consider not only the presence, but also the size of the Audit Committee, arguing that a lean committee brings greater efficiency (Ho et al., 2009; Hsu \& Petchsakulwong, 2010).

The Risk Committee is among the other committees considered most relevant for the effectiveness of governance (Cummins, Dionne, Gagné, \& Nouira, 2009; Ng et al., 2012; Wu et al., 2016). Its contribution should be found especially in controlling risk, rather than improving company's performance. The Remuneration committee stands out with the function to offer the board impartial opinions and recommendations on the remuneration and incentive schemes of employees and management, including the CEO (Diacon \& O'Sullivan, 1995; O'Sullivan \& Diacon, 1999). It is generally composed by external directors. The Finance Committee has also received attention in the insurance studies, given the importance of the investment function for the management of the company. Within this research area, scholars also consider the degree of independence of the intra-board committee or the percentage of independent directors within this body (Ho et al., 2009; Hsu et al., 2015).

\section{Debt policies and dividend distribution policies}

Multi-sector governance studies include, as internal instruments, debt policies, which limit the discretion of managers for the use of important financial resources (Boubakri et al., 2006). Sometimes these mechanisms are reinforced by covenants and clauses to protect creditors. However, the specificity of the financial cycle of insurance companies, with premium receipts anticipating claims exits, reduces the frequency of external indebtedness through financial instruments. And technical reserves, considered a liability to policyholders, are not comparable to traditional debt instruments and therefore do not fit into this classification. Another internal mechanisms includes the policies of distributing extraordinary dividends that may induce managers to maximize the performance of the company by aligning their interests to those of shareholders.

Some control mechanisms, external or internal, are not applicable in relation to a number of variables, among which scholars indicate as the main one, the ownership model: the mutual insurers do not apply mechanisms typical of the capital markets (take over, equity incentive plans, management ownership, control action carried out by block holders or institutional investors) (Mayers et al., 1997; Mayers \& Smith, 2010). For equity-based companies, on the other hand, the breadth of the range of external mechanisms depends on whether the company is listed or not and the characteristics of shareholders. As a result, there is a greater use of "internal" control mechanisms such as the role of independent directors for mutuals. In the field of insurance, many studies have considered this aspect: among others, we mention Diacon and O'Sullivan, (1995), O'Sullivan and Diacon (1999), Boubakri et al. (2006), He and Sommer (2010), Lambalk and de Graaf (2017), He et al. (2011), Mayers et al. (1997).

Parallel developments in this line of inquiry relate to the relationship between ownership, intensity of governance and choices of the risk branches in which to operate, given that some risk branches require greater discretion of decision-making on the part of the CEO (Managerial Discretion Hypothesis - MDH) and, therefore, less stringent internal controls (Marx et al., 2001; Mayers \& Smith, 1981, 1994; Miller, 2011; Pottier \& Sommer, 1997). As a result, mutuals tend to operate in "short tail" or more predictable risk branches than equity-based companies, while within this second class of companies there are choices of risk branches consistent with the MDH hypothesis (Lamm-Tennant \& Starks, 1993; Mayers \& Smith, 1981, 1988, 1994).

\section{A Bibliometric Analysis of Research Networks on Governance Issues in the Insurance Field}

Based on the theoretical premises and the research strands outlined above, the study complements the review by employing a bibliometric analysis through content analysis and co-authorship analysis of insurance governance studies. The aim is to identify clusters that constitute the current intellectual structure of studies in this area and determine the conceptual relationships between the different clusters and the most influential authors (Note 2).

Contributions and their bibliographic references were collected using the Web of Science and Scopus databases, integrating the results with papers available on other databases that contained additional papers and research.

By minimizing the values for the number of authors' publications, a complete map of all publications, including possible minor studies is obtained. The analysis of publications also allows to visualize how the scientific community investigating the topic of insurance governance actually appears poorly connected, apart from few exceptions. The size of the "nodes" indicates the number of contributions of an author: Figure 1 shows that only around a dozen authors have more than two publications on the topic. The relatively small number of co-authorships should not be surprising: for some, insurance studies are a mere complementary study of governance in other areas, or they are carried out with less homogeneous samples (banks, insurances and other 
financial intermediaries), or, as experts in this business sector insurance governance is one only of the various topics of investigation in the field of insurance intermediation, or, simply, the researcher is at the beginning of his scientific production and is relatively isolated.

The first cluster is the most populated in terms of participants and sees Sommer and He to emerge, connected to other authors of lower productivity, while the other clusters are made of Adams and Hardwick, and Lai and Diacon.

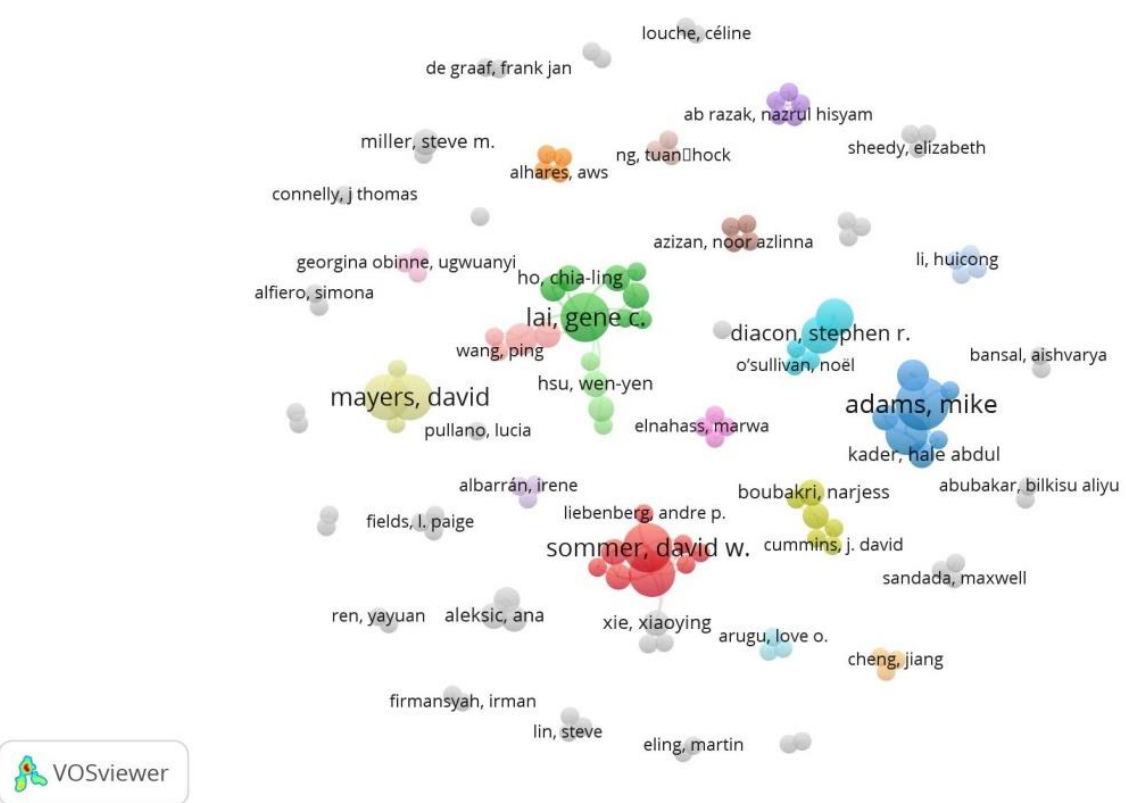

Figure 1. Co-authorship analysis on governance in the insurance industry carried out with Vosviewer software in the period 1985-2019 (Minimum number of publications $=1$ )

The map highlights both the scientific links between authors in the production of papers and the intensity of these links: the thicker the line that connects them, the higher the number of scientific contributions in which scholars have worked together. As an example, see the links between Sommer and He's scientific output, characterized by various collaborations between the two authors, and Lai, characterized by co-authorship with different researchers (Figure 2).
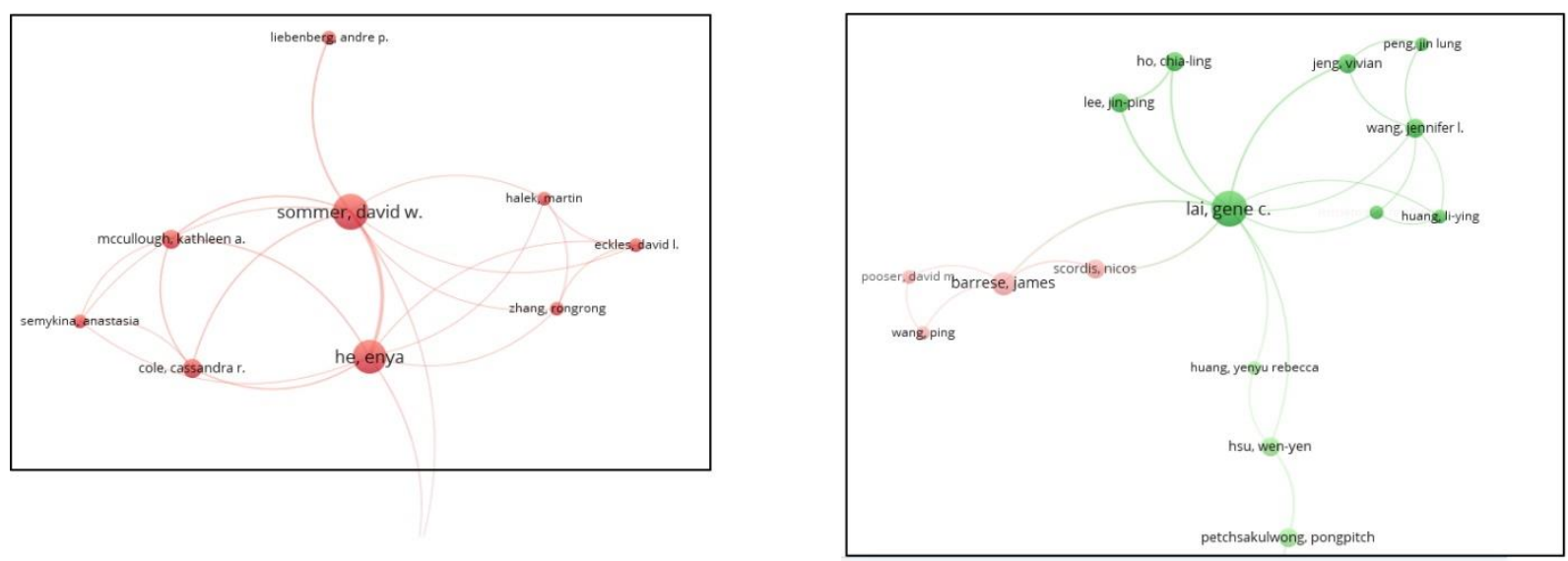

Figure 2. Co-authorship analysis: Sommer and He (network on the left); Lai (network on the right)

When looking at network and year of publication, studies on governance in the insurance field appear as relatively recent and the minor contributions have been published in the last few years (Figure 3). Additionally, the most isolated contributions are mainly related to European countries and developing countries, proving an 
undoubted increasing interest in governance issues by scholars, which is however limited by a lack of accessible data for Europe and emerging countries.

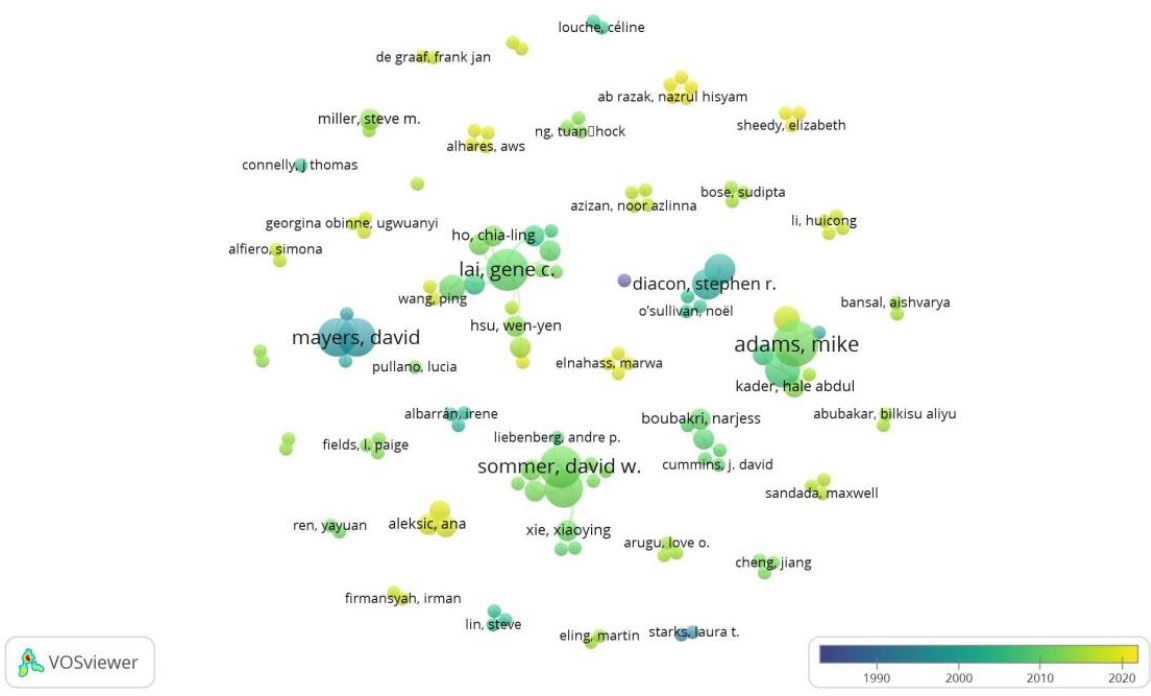

Figure 3. Co-authorship analysis on the subject of governance in the insurance industry carried out with Vosviewer software in the period 1985-2019 (Minimum number of publications =1)

Note. Colors closer to blue represent the oldest publications, while the ones closest to yellow are the most recent.

We also carry out a textual analysis, related to the frequency and combinations of keywords within the title and/or abstract of the articles contained in the sample of studies analyzed (Figure 4). The minimum number of "co-occurrences" (by default assumed to 3 ) has been set to 10 to better identify clusters. The size of the node/cluster reflects, in this specific case, the number of publications that contain that keyword/term. Closer nodes contain terms with strong relationships. The thickness of the curves that join the nodes reflects the frequency of the coexistence of the two terms in the same abstract or title. At the individual node level, similar to what was previously highlighted about co-authors, it is possible to have a greater detail of the terms contained in a cluster, and therefore the relationships between terms in that group, but used less frequently, also appear. The color of the clusters identifies the set of terms assigned to that node in order to identify sub-groups of terms, in relation to each other, within a given line of studies. The green cluster is essentially related to research focusing on proprietary structures and the effectiveness of the composition and independence of the board in risk reduction. The blue group, on the other hand, relates to the relationship between the governance instruments ("board" and "board characteristics") and the performance declined as accounting or market performance (blue clusters) or as efficiency (red nodes).

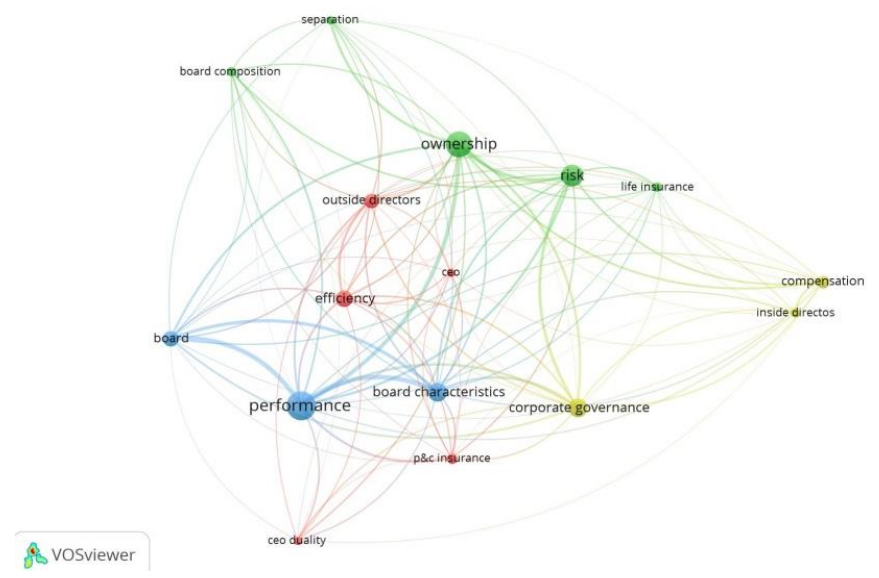

Figure 4. Co-occurrence analysis on governance in the insurance industry carried out with Vosviewer software from 1985-2019

Note. Binary count, minimum 10 recurrences, only 17 terms excluding non-significant terms for representation purposes (insurance, papers, study, period, evidence, effect, impact, relation and relationship). 
In addition, studies that take into account proprietary structures analyze, in many cases, performance and/or risk as dependent variables (Figure 5). There is also a strong relationship between studies of proprietary structures and risk control, as can be seen both from the small distance between the two nodes and from the thickness of the line that connects them. Other aspects considered are the board as a whole (structure, size), board characteristics (in terms of experience and skills), separation of CEO and Chairman roles, as well as the weight of outside directors; the respective lines are thicker. Regarding the latter, these issues appear particularly close to those of ownership, as well as to risk considerations.

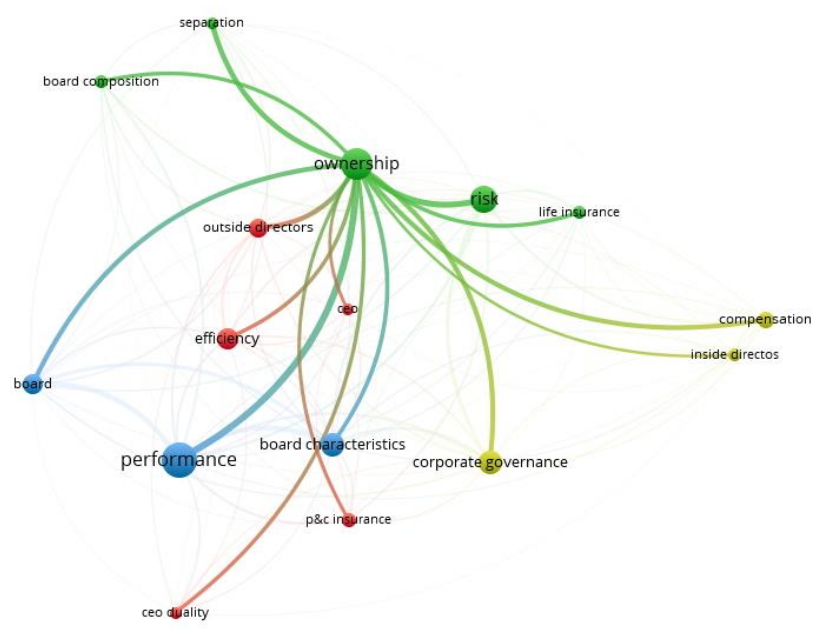

Figure 5. Relationships between ownership and other terms

\section{The Meta-Analysis on the Governance and Performance Relationship of Insurance Companies}

The meta-analysis is employed in the study to provide an assessment of the relationship between the governance and performance of insurance companies as it emerges from the literature on the topic. To this end, the focus is on two common governance measures employed: the size of the board and the presence of independent directors (usually expressed as a percentage and referred to as "outside directors").

The analysis is performed as follows: 1 . All the studies testing this relationship were identified according to the following criteria: the presence of keywords ("performance"; "governance" and "insurance") in the main scientific databases considered (Scopus and WoS). Following the first output, the research was integrated with the references cited by each paper (Note 3).

2. From all the studies identified, we selected only the empirical studies that specifically include a regression that tests the relationship between corporate governance variables (as independent or control variables) and performance (as dependent variable) (Note 4).

After finalizing the dataset of the studies, a meta-analysis is performed. Through the aggregation of results of various studies, the meta-analysis is able to provide an estimate of the relationship between two variables, correcting for various statistical artifacts, integrating the mixed empirical evidence. By doing so, we are able to develop a better understanding of the existing, suggest new explanatory theories and increase knowledge. In the meta-analysis procedure, each observed correlation is weighted by the sample size in the study to contribute to the determination of the weighted average correlations between all the studies that compose the analysis. In order to estimate the variability of the relationship between the variables studied, the standard deviation of the observed correlations is calculated (among the studies applying meta-analysis to banking and finance issues, see Rosenbusch, Brinckmann, \& Muller, 2013; Lagasio, 2018; Tanda \& Manzi, 2019).

To conduct the analysis, we focus on the regression coefficients and their error/significance measures (standard error, t-statistic or p-value) and transform them into partial correlation coefficients.

When the study develops multiple regression estimations for the same dependent variable based on numerically different samples (observations), the result for the larger sample is selected, whereas when different models are applied to the same sample (observations) the average values of the different models are considered.

In total we obtain 28 studies and 113 coefficients associated with the relationship tested by the studies (of which 61 for the size of the board and 52 for the percentage of outside directors). The studies are almost evenly distributed between samples from emerging countries (15 studies, 70 coefficients) and developed countries (13 
studies, 43 coefficients). The majority of studies (13 studies) investigate insurance companies active in both life and non-life branches ( 44 coefficients); 11 focus on non-life branches ( 47 coefficients), while only 4 are focused on the life branch (22 coefficients).

Table 2 shows for each study, the measure of performance, the board variable, the geographical area and the branch investigated (life, non-life or both).

Table 2. Key performance measures and independent and control variables of studies analyzed

\begin{tabular}{|c|c|c|c|c|c|}
\hline Authors & Year & $\begin{array}{c}\text { Performance } \\
\text { proxy }\end{array}$ & Board variable & $\begin{array}{c}\text { Geographical area } \\
(\mathrm{D}=\text { developed countries; } \\
\text { E = emerging countries }\end{array}$ & Branch \\
\hline O'Sullivan, N.; Diacon S.R. & 2003 & Growth & $\%$ outside directors & $\mathrm{D}$ & life \\
\hline Connelly J.T., Limpaphayom P. & 2004 & profitability & $\log ($ size $) \%$ outside directors & $\mathrm{E}$ & life \\
\hline Barrese, J.; Lai, G.; Scordis, N. & 2005 & profitability & $\%$ outside directors & $\mathrm{D}$ & non-life \\
\hline Wang, J.L.; Jeng, V.; Peng, J. L. & 2007 & $\begin{array}{l}\text { efficiency and } \\
\text { profitability }\end{array}$ & size & $\mathrm{E}$ & non-life \\
\hline Wang, J.L.; Jeng, V.; Peng, J. L. & 2007 & $\begin{array}{l}\text { efficiency and } \\
\text { profitability }\end{array}$ & size & $\mathrm{E}$ & life \\
\hline Boubakri, N.; Dionne, G.; Triki, T. & 2008 & profitability & $\%$ outside directors & $\mathrm{D}$ & non-life \\
\hline Hsu, W-Y; Pongpitch, P. & 2010 & efficiency & $\log ($ size $) \%$ outside directors & E & non-life \\
\hline $\begin{array}{l}\text { Kader, H.A.; Adams, M.; } \\
\text { Hardwick, P. }\end{array}$ & 2010 & efficiency & size $\%$ outside directors & $\mathrm{E}$ & non-life \\
\hline $\begin{array}{l}\text { Huang, L.-Y.; Lai, G. C.; } \\
\text { McNamara, M.; Wang, J. }\end{array}$ & 2011 & efficiency & size $\%$ outside directors & $\mathrm{D}$ & life and non-life \\
\hline Najjar, N. & 2012 & profitability & size & $\mathrm{E}$ & life and non-life \\
\hline Tornyeva, K.; Wereko, T. & 2012 & profitability & size $\%$ outside directors & $\mathrm{E}$ & life and non-life \\
\hline $\begin{array}{l}\text { Kader, A.H.; Adams, M.; } \\
\text { Hardwick, P.; Kwon, }\end{array}$ & 2014 & efficiency & size $\%$ outside directors & E & life and non-life \\
\hline Fekadu, G.W. & 2015 & profitability & size $\%$ outside directors & $\mathrm{E}$ & life and non-life \\
\hline Hsu W.Y., Huang Y., Lai G. & 2015 & growth & size $\%$ outside directors & $\mathrm{D}$ & non-life \\
\hline Adams, M.; Jiang W. & 2016 & profitability & size & $\mathrm{D}$ & non-life \\
\hline Alfiero, S.; Venuti, F. & 2016 & resilience & size & $\mathrm{D}$ & life and non-life \\
\hline Cai, W.; Lu, W.; Xie, X. & 2016 & profitability & size $\%$ outside directors & $\mathrm{D}$ & life \\
\hline Adams, M.; Jiang W. & 2017 & profitability & size $\%$ outside directors & $\mathrm{D}$ & non-life \\
\hline Adams, M.; Jiang W. & 2017 & profitability & size $\%$ outside directors & $\mathrm{D}$ & non-life \\
\hline $\begin{array}{l}\text { Ibe, H.C.A; Obinne, U.G.; } \\
\text { Chinelo, O.O. }\end{array}$ & 2017 & profitability & size $\%$ outside directors & $\mathrm{E}$ & life and non-life \\
\hline Deev, O.; Khazalia, N. & 2017 & profitability & size $\%$ outside directors & $\mathrm{D}$ & life and non-life \\
\hline Hidayat, I.P.; Firmansyah, I. & 2017 & profitability & size & E & life and non-life \\
\hline $\begin{array}{l}\text { Wu, Y.C.; Kweh, Q.L.; Lu, W.M.; } \\
\text { Azizan, N.A. }\end{array}$ & 2017 & efficiency & $\log ($ size $) \%$ outside directors & $\mathrm{E}$ & life and non-life \\
\hline Datta N. & 2018 & profitability & size & $\mathrm{D}$ & life and non-life \\
\hline $\begin{array}{l}\text { Elamer, A.A.; AlHares, A.; Ntim, } \\
\text { C.G.; Benyazid, I. }\end{array}$ & 2018 & resilience & $\begin{array}{c}\text { size } \\
\% \text { outside directors }\end{array}$ & $\mathrm{D}$ & life and non-life \\
\hline $\begin{array}{l}\text { Karbhari, Y; Muye, I.M.; Hasan, } \\
\text { A.F.; Elnahass, M. }\end{array}$ & 2018 & efficiency & size $\%$ outside directors & E & non-life \\
\hline $\begin{array}{l}\text { Petchsakulwong, P.; Jansakul, N. } \\
\text { Lee, H. S.; Cheng, F.F.; Har, W.M.; } \\
\text { Nassir, A.M.; Ab Razak, N.H. }\end{array}$ & $\begin{array}{l}2018 \\
2019\end{array}$ & $\begin{array}{l}\text { profitability } \\
\text { efficiency }\end{array}$ & $\begin{array}{l}\log (\text { size }) \% \text { outside directors } \\
\text { size } \% \text { outside directors }\end{array}$ & $\begin{array}{l}\mathrm{E} \\
\mathrm{E}\end{array}$ & $\begin{array}{l}\text { non-life } \\
\text { life and non-life }\end{array}$ \\
\hline
\end{tabular}

With reference to the governance explanatory variable, the percentage of outside directors is measured evenly in all the studies considered, while size is measured as the number of directors on the board in the majority of cases (49 coefficients), and as a logarithm of the number of directors in 12 other cases.

Given the various approaches used to measure performance, these are classified according to two criteria: the origin of measurement (accounting values and market values) and type of performance (profitability, efficiency, growth and resilience) (Note 5).

Table 3 shows the number of relationships included in the survey, differentiating on the basis of performance measure, geographical area, branch type. Table 4, on the other hand, shows descriptive statistics for the coefficients associated with the relationship between performance and governance. 
Table 3. Distribution of relationships investigated by the studies included in the meta-analysis

\begin{tabular}{|c|c|c|c|}
\hline Performance measure & Size & \% outside directors & Total \\
\hline Profitability & 32 & 26 & 58 \\
\hline Developed & 17 & 15 & 31 \\
\hline Life and non-life & 7 & 6 & 13 \\
\hline Life & 2 & 2 & 4 \\
\hline Non-life & 8 & 7 & 15 \\
\hline Emerging & 15 & 11 & 26 \\
\hline Life and non-life & 6 & 4 & 10 \\
\hline Life & 6 & 5 & 11 \\
\hline Non-life & 3 & 2 & 5 \\
\hline Efficiency & 27 & 21 & 48 \\
\hline Developed & 2 & 2 & 4 \\
\hline Life and non-life & 2 & 2 & 4 \\
\hline Emerging & 25 & 19 & 44 \\
\hline Life and non-life & 8 & 8 & 16 \\
\hline Life & 3 & & 3 \\
\hline Non-life & 14 & 11 & 25 \\
\hline Growth & 1 & 5 & 6 \\
\hline Developed & 1 & 5 & 6 \\
\hline Life & & 4 & 4 \\
\hline Non-life & 1 & 1 & 2 \\
\hline Resilience & 1 & & 1 \\
\hline Developed & 1 & & 1 \\
\hline Life and non-life & 1 & & 1 \\
\hline Total & 61 & 52 & 113 \\
\hline
\end{tabular}

Table 4. Descriptive statistics of the independent variables

\begin{tabular}{lccccccc}
\hline $\begin{array}{l}\text { Governance } \\
\text { measure }\end{array}$ & Average & $\begin{array}{c}\text { Standard } \\
\text { deviation }\end{array}$ & Min & Max & Observ. & $\begin{array}{c}\text { Number of negative } \\
\text { coef. }\end{array}$ & $\begin{array}{c}\text { Number of positive } \\
\text { coef. }\end{array}$ \\
\hline $\begin{array}{l}\text { Board size } \\
\% \text { outside directors }\end{array}$ & 0.0327 & 0.1680 & -0.4356 & 0.4285 & 61 & 18 & 43 \\
\end{tabular}

For board size, 61 relations were found, (43 positive and 18 negative), while for outside directors, we have 51 coefficients ( 35 positive and 16 negative): the positive effect of board size and outside directors on performance measures seems to prevail.

The meta-analysis for the variable board size shows a positive sign for all performance measures, but is only significant for measures related to profitability and growth (the latter refers to only one study) (Table 5). On the other hand, outside directors' impact on performance appears positive and significant only for profitability measures, while it is positive, but not significant, for the other measures. The detail of each study in terms of the contribution to the relationship between governance and performance is identifiable in the forest plots reported in Figure 7 and 8.

The main evidence confirms that a larger board might contribute to performance by bringing more competences and skills and a more diversified background to the management body. Additionally, the role of outside directors appears to be effective in moderating agency conflicts and thus contributing to better performance.

Table 5. Descriptive statistics of the relationship between performance and independent variables

\begin{tabular}{lcccccc}
\hline \multirow{2}{*}{$\begin{array}{l}\text { Performance } \\
\text { measure }\end{array}$} & \multicolumn{2}{c}{ Size } & \multicolumn{3}{c}{ \% outside directors } \\
\cline { 2 - 7 } Profitability & Coefficient & p-value & Number of estimates & Coefficient & p-value & Number of estimates \\
Efficiency & 2.81 & 0.005 & 30 & 2.57 & 0.010 & 23 \\
Growth & 1.64 & 0.101 & 27 & 0.23 & 0.820 & 21 \\
Resilience & 1.89 & 0.058 & 1 & 0.12 & 0.901 & 5 \\
Overall & 1.15 & 0.252 & 3 & 0.77 & 0.441 & 2 \\
\hline
\end{tabular}


The meta-analysis is further enriched by distinguishing the studies on the basis of other characteristics, among which we include the geographical area (emerging or developed countries), the branch of the insurance companies studied (life, non-life or both) and the accounting or market nature of the performance measured used (Table 6).

Results confirm the positive direction of the relationship between governance and performance, especially for developed countries and for the non-life branch, in particular when considering accounting measures (e.g. ROA and $\mathrm{ROE}$ ).

Table 6. Descriptive statistics of the relationship between performance measure and independent variables differentiating by sample characteristic

\begin{tabular}{|c|c|c|c|c|c|c|}
\hline \multirow[b]{2}{*}{ Sample breakdown } & \multicolumn{3}{|r|}{ Size } & \multicolumn{3}{|c|}{ \% outside directors } \\
\hline & Coefficient & p-value & Number of estimates & Coefficient & p-value & Number of estimates \\
\hline \multicolumn{7}{|l|}{ Geographical area } \\
\hline Developed & 3.03 & 0.002 & 21 & 1.97 & 0.049 & 21 \\
\hline Emerging & 1.44 & 0.150 & 40 & 1.06 & 0.289 & 30 \\
\hline \multicolumn{7}{|l|}{ Branch } \\
\hline Life & 0.61 & 0.542 & 11 & 1.32 & 0.187 & 10 \\
\hline Non-life & 4.35 & 0.000 & 26 & 1.82 & 0.068 & 21 \\
\hline Life and non-life & 0.58 & 0.561 & 24 & 0.46 & 0.642 & 20 \\
\hline \multicolumn{7}{|c|}{ Source of performance measures } \\
\hline Accounting measure & 3.01 & 0.003 & 58 & 1.87 & 0.061 & 46 \\
\hline Market measure & 1.70 & 0.089 & 3 & 1.40 & 0.161 & 5 \\
\hline
\end{tabular}

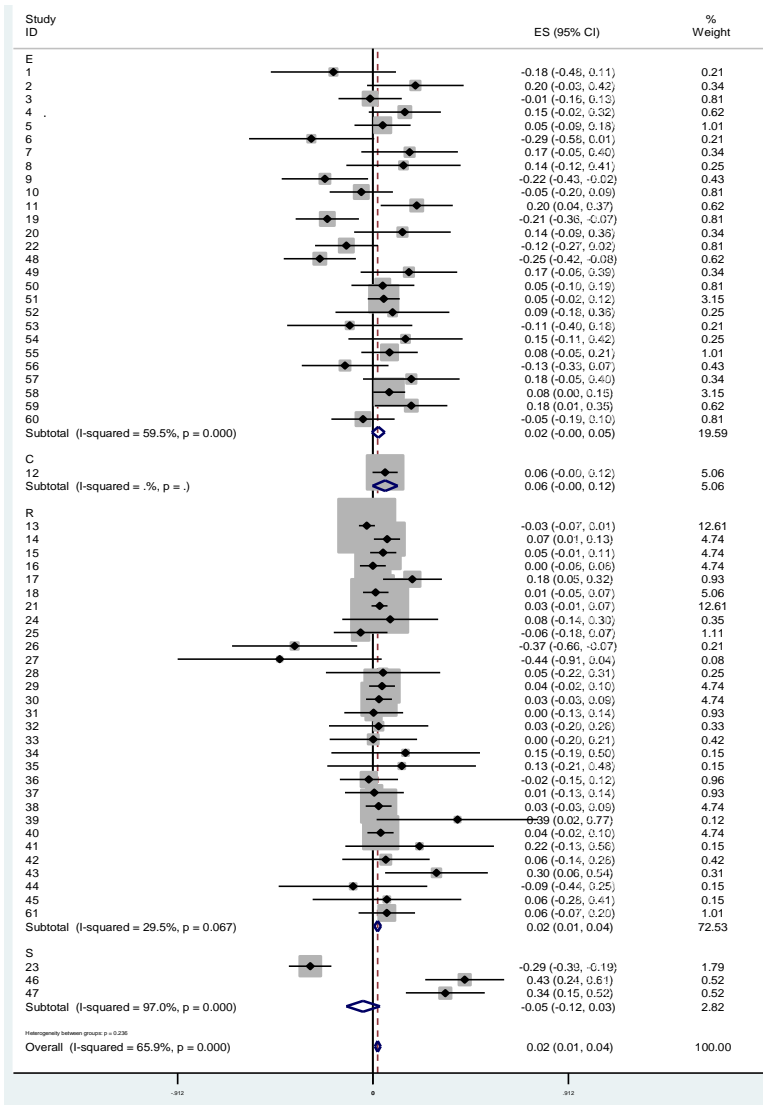

Figure 6. Forest plot for "size"

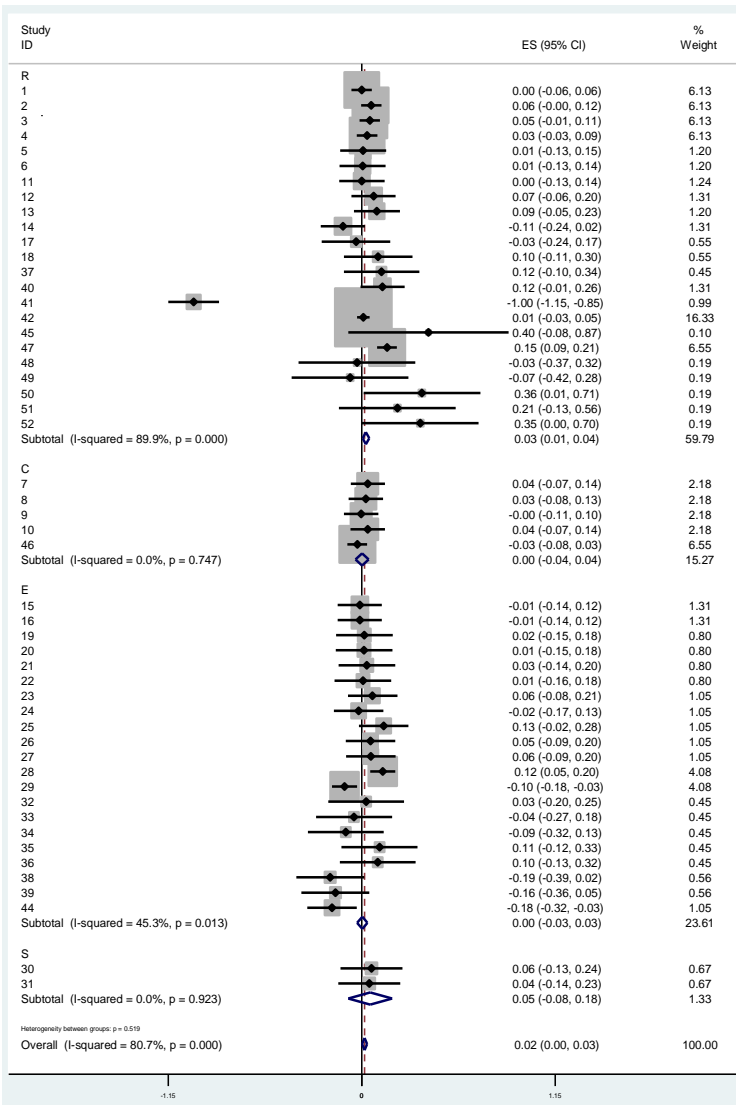

Figure 7. Forest plot for "\%outside directors"

\section{Conclusions}

Corporate governance has always been a key issue in business management, but has received increasing attention in recent years especially after the 2008-2009 crisis that has highlighted several weaknesses in the 
governance of financial intermediaries. With reference to the financial sector, insurance companies' corporate governance has received less attention than that of the banking sector, but it has provided equally interesting results and contributions for the variety of investigative ideas.

This paper provides an updated analysis of the literature and empirical research and highlights the variety of corporate governance aspects investigated in the insurance sector, the main lines of investigation drawn and the results achieved in the analysis of the relationship between individual governance mechanisms and the effectiveness of governance. In addition, specific issues in the insurance sector emerged, such as the relationship between governance characteristics and risk branch choices. What emerges is that contrasting results still persist and hence further research is welcome.

Bibliometric mapping of co-author and co-author networks allowed us to visualize authors who more than others have influenced research paths, and whether and how much they operate within scientific networks or in isolation. The representation of scientific networks shows indeed that more central studies on the topic are relatively sparse and sparsely populated and that they are essentially related to the US context. On the other hand, recent scientific production consists of increasing contributions from isolated researchers and is related to new geographical contexts.

The representation of the terminology networks highlights the prevalence of studies that consider the organizational structure of the company and the consequent conditioning on the choices related to governance tools when analyzing the effectiveness of corporate governance settings. In the context of these studies, there is a strong focus on the consequences of governance choices in terms of risk and economic performance.

The meta-analysis performed in this study additionally shows that most governance studies in the insurance industry rely on governance measures that are mostly common in other areas of research and industries (i.e., board size and percentage of independents) and focus on the impact of these two variables on a diverse set of performance measures. These relate to both accounting (ROA, ROE) and market profitability (equity returns or Tobin's Q), but also efficiency, or - to a lesser extent - to the growth and resilience proxies of the insurance company. Most studies confirm a positive contribution of the number of directors and the weight of independents to performance (variously measured, especially with regard to the profitability of the company).

As a final check, we also implement a meta-regression analysis, to evaluate how the characteristics of the different studies analyzed (geographic area, the sample used, quality of research) influence the evidence provided by the relative empirical investigation. Results confirm the positive direction of the relationship between governance and performance (especially accounting measures), in particular for developed countries and for the non-life branch.

Our study presents some limitations: despite relying on the most used databases, it might ignore some research or studies that are not accessible through Scopus or WOS. Additionally, the meta-analysis might be improved focusing on other key variables that describe corporate governance, such as the role of committees or the gender representation or other forms of diversity (age, geographical provenance, etc.) within the board of directors. These and other possible analyses on the role of internal and external mechanisms in insurance companies should be welcome, especially with reference to non-US samples and emerging economies, to gain a better understanding of corporate governance mechanisms in insurance companies and the peculiarities and differences - if any - with respect with the more investigated governance in banks. As a hint for further research, also the peculiarities of governance in bancassurance can be an interesting research path to follow.

\section{Acknowledgments}

This work was supported by the Uniss for Research Fund 2020.

\section{References}

Adams, M., \& Hossain, M. (1998). Managerial discretion and voluntary disclosure: Empirical evidence from the New Zealand life insurance industry. Journal of Accounting and Public Policy, 17(3), 245-281. https://doi.org/10.1016/S0278-4254(98)10003-0

Adams, M., \& Jiang, W. (2016). Do outside directors influence the financial performance of risk-trading firms? Evidence from the United Kingdom (UK) insurance industry. Journal of Banking \& Finance, 64, 36-51. https://doi.org/10.1016/j.jbankfin.2015.11.018

Adams, M., \& Jiang, W. (2017a). Do Chief Executives' Traits Affect the Financial Performance of Risk-trading Firms? Evidence from the UK Insurance Industry: CEOs' Traits and Performance in Insurance. British Journal of Management, 28(3), 481-501. https://doi.org/10.1111/1467-8551.12222 
Adams, M., \& Jiang, W. (2017b). Do Financial Experts on the Board Matter? An Empirical Test From the United Kingdom's Non-Life Insurance Industry. Journal of Accounting, Auditing \& Finance. https://doi.org/10.1177/0148558X17705201

Bansal, B., \& Bansal, A. (2014). Corporate Governance and Risk Management in Insurance Sector: A review of literature. International Journal of Scientific and Research Publications, 4(10), 3407-3409. Retrieved from http://www.ijsrp.org/research-paper-1014.php?rp=P343193

Barrese, J., Lai, G. C., \& Scordis, N. (2005). Ownership Concentration and Governance in the U.S. Insurance Industry (SSRN Scholarly Paper N. ID 2117465). Retrieved from https://papers.ssrn.com/abstract=2117465.

Barrese, J., Lai, G., \& Scordis, N. (2007). Ownership Concentration and Governance in the U.S. Insurance Industry. Journal of Insurance Issues, 30(1), 1-30. https://doi.org/10.2307/41946267

Boubakri, N. (2011). Corporate Governance and Issues from the Insurance Industry. Journal of Risk and Insurance, Special Issue on Corporate Governance (September 2011), 78(3), 501-518, https://doi.org/10.2307/23019980

Boubakri, N., Dionne, G., \& Triki, T. (2006). Consolidation and value creation in the insurance industry: The role of governance. SSRN Electronic Journal, 56-68. 10.2139/ssrn.908660. https://doi.org/10.2139/ssrn.908660

Cai, W., Lu, W., \& Xie, X. (2009). Internal Corporate Control and the Dynamics of Post-Acquisition Boards: Evidence of U.S. Life Insurers. International Journal of Business, 21(2), 132-150. Retrieved from http://www.craig.csufresno.edu/ijb/

Cheng, J., Elyasiani, E., \& Jia, J. J. (2011). Institutional Ownership Stability and Risk Taking: Evidence From the Life-Health Insurance Industry. Journal of Risk and Insurance. https://doi.org/10.1111/j.1539-6975.2011.01427.x

Cole, C. R., He, E., McCullough, K. A., \& Sommer, D. W. (2011). Separation of Ownership and Management: Implications for Risk-Taking Behavior. Risk Management and Insurance Review, 14(1), 49-71. https://doi.org/10.1111/j.1540-6296.2010.01192.x

Cole, C. R., He, E., McCullough, K. A., Semykina, A., \& Sommer, D. W. (2011). An Empirical Examination of Stakeholder Groups as Monitoring Sources in Corporate Governance. Journal of Risk and Insurance. https://doi.org/10.1111/j.1539-6975.2011.01428.x

Connelly, J. T. (2004). Board Characteristics and Firm Performance: Evidence from the Life Insurance Industry in Thailand. Chulalongkorn Journal of Economics, 16(2), 101-124. Retrieved from https://www.econ.chula.ac.th/public/publication/journal/2004/cje160201.pdf

Cummins, J. D., Dionne, G., Gagné, R., \& Nouira, A. H. (2009). Efficiency of insurance firms with endogenous risk management and financial intermediation activities. Journal of Productivity Analysis, 32(2), 145-159. https://doi.org/10.1007/s11123-009-0131-0

Deev, O., \& Khazalia, N. (2017). Corporate Governance, Social Responsibility and Financial Performance of European Insurers. Acta Universitatis Agriculturae et Silviculturae Mendelianae Brunensis, 65(6), 1873-1888. https://doi.org/10.11118/actaun201765061873

Diacon, S. R., \& O'Sullivan, N. (1995). Does corporate governance influence performance? Some evidence from U.K. insurance companies. International Review of Law and Economics, 15(4), 405-424. https://doi.org/10.1016/0144-8188(95)00038-0

Diacon, S., O'Brien, C., Drake, L., \& O'Sullivan, N. (2005). Mutual life offices: A contribution to the governance debate. Retrieved from https://www.researchgate.net/publication/228907850_Mutual_Life_Offices_A_Contribution_to_the_Gover nance_Debate

Doherty, N. A., \& Dionne, G. (1993). Insurance with Undiversifiable Risk: Contract Structure and Organizational Form of Insurance Firms. Journal of Risk and Uncertainty, 6(2), 187-203.

Eckles, D. L., Halek, M., He, E., Sommer, D. W., \& Zhang, R. (2011). Earnings Smoothing, Executive Compensation, and Corporate Governance: Evidence From the Property-Liability Insurance Industry. Journal of Risk and Insurance. https://doi.org/10.1111/j.1539-6975.2011.01417.x

Elamer, A. A., AlHares, A., Ntim, C. G., \& Benyazid, I. (2018). The corporate governance-risk-taking nexus: Evidence from insurance companies. International Journal of Ethics and Systems, 34(4), 493-509. 
https://doi.org/10.1108/IJOES-07-2018-0103

Eling, M., \& Marek, S. D. (2014). Corporate Governance and Risk Taking: Evidence From the U.K. and German Insurance Markets. Journal of Risk and Insurance, 81(3), 653-682. https://doi.org/10.1111/j.1539-6975.2012.01510.x

Fama, E. F., \& Jensen, M. C. (1983) Separation of ownership and control. Journal of Law and Economics, 26(2), 301-25. http://dx.doi.org/10.1086/467037

Fekadu, G. W. (2015). Corporate governance on financial performance of insurance industry. Corporate Ownership and Control, 13(1-10), 1202-1209. https://doi.org/10.22495/cocv13i1c10p7

Garba, T., \& Abubakar, B. A. (2014). Corporate board diversity and financial performance of insurance companies in Nigeria: an application of panel data approach. Asian Economic and Financial Review, 257-277. Retrieved from http://www.aessweb.com/download.php?id=2419

Genetay, N. (1999). Ownership structure and performance in UK life offices. European Management Journal, 17(1), 107-115. https://doi.org/10.1016/S0263-2373(98)00068-1

Gugong, B. K., Arugu, L. O., \& Dandago, K. I. (2014). The Impact of Ownership Structure on the Financial Performance of Listed Insurance Firms in Nigeria. International Journal of Academic Research in Accounting, Finance and Management Sciences, 409-416. https://doi.org/10.6007/IJARAFMS/v4-i1/698

Hansmann, H. (1985). The Organization of Insurance Companies: Mutual versus Stock. Journal of Law, Economics, \& Organization, 1(1), 125-153. https://doi.org/10.1093/oxfordjournals.jleo.a036884

Hardwick, P., \& Letza, S. (1999). The Relative Performance of Mutual and Proprietary Life Insurance Companies in the UK: An Exploratory Study. Working Paper. Poole, UK: Bournemouth University School of Finance and Law. Retrieved from http://eprints.bournemouth.ac.uk/3073/1/292.pdf

Hardwick, P., Adams, M., \& Zou, H. (2003). Corporate Governance and Cost Efficiency in the United Kingdom Life Insurance Industry. European Business Management School, London, UK. Retrieved from https://www.researchgate.net/publication/251427206_Corporate_Governance_and_Cost_Efficiency_in_the _United_Kingdom_Life_Insurance_Industry

Hardwick, P., Adams, M., \& Zou, H. (2011). Board Characteristics and Profit Efficiency in the United Kingdom Life Insurance Industry. Journal of Business Finance \& Accounting, 38(7-8), 987-1015. https://doi.org/10.1111/j.1468-5957.2011.02255.x

Harris, R. J., Bradburn, M. J., Deeks, J. J. Harbord, R. M., Altman D. G., \& Sterne J. A. (2008). Metan: Fixedand Random-Effects Meta-analysis. The Stata Journal: Promoting Communications on Statistics and Stata, 8(1), 3-28. https://doi.org/10.1177/1536867X0800800102

He, E., \& Sommer, D. W. (2010). Separation of Ownership and Control: Implications for Board Composition. Journal of Risk and Insurance, 77(2), 265-295. https://doi.org/10.1111/j.1539-6975.2010.01351.x

He, E., \& Sommer, D. W. (2011). CEO Turnover and Ownership Structure: Evidence From the U.S. Property-Liability Insurance Industry. Journal of Risk and Insurance. https://doi.org/10.1111/j.1539-6975.2011.01416.x

He, E., Sommer, D. W., \& Xie, X. (2011). The Impact of CEO Turnover on Property-Liability Insurer Performance. Journal of Risk and Insurance. https://doi.org/10.1111/j.1539-6975.2011.01411.x

Hidayat, I. P., \& Firmansyah, I. (2017). Determinants of Financial Performance in The Indonesian Islamic Insurance Industry. ETIKONOMI, 16(1), 1-12. https://doi.org/10.15408/etk.v16i1.4648

Higgins, J. P. T., \& Thompson, S. G. (2004). Controlling the Risk of Spurious Findings from Meta-regression. Statistics in Medicine, 23, 1663-1682. https://doi.org/10.1002/sim.1752

Ho, C. L., Lai, G. C., \& Lee, J. P. (2013). Organizational Structure, Board Composition, and Risk Taking in the U.S. Property Casualty Insurance Industry. Journal of Risk and Insurance, 80(1), 169-203. https://doi.org/10.1111/j.1539-6975.2012.01464.x

Ho, C. L., Lai, G., \& Lee, J. P. (2009). Corporate governance, audit quality and risk taking in the U.S. property casualty insurance industry. Corporate Ownership and Control, 7(1). https://doi.org/10.22495/cocv7i1p8

Hsu, W. Y., \& Petchsakulwong, P. (2010). The Impact of Corporate Governance on the Efficiency Performance of the Thai Non-Life Insurance Industry. The Geneva Papers on Risk and Insurance - Issues and Practice, 
35(S1), S28-S49. https://doi.org/10.1057/gpp.2010.30

Hsu, W. Y., Huang, Y. R., \& Lai, G. (2015). Corporate Governance and Cash Holdings: Evidence From the U.S. Property-Liability Insurance Industry. Journal of Risk and Insurance, 82(3), 715-748. https://doi.org/10.1111/jori.12049

Huang, L.-Y., Lai, G. C., McNamara, M., \& Wang, J. (2011). Corporate Governance and Efficiency: Evidence From U.S. Property-Liability Insurance Industry. Journal of Risk and Insurance, 519-550. https://doi.org/10.1111/j.1539-6975.2011.01410.x

Ibe, H. C. A. I., Georgina, O. U., \& Ogochukwu, C. O. (2017). Effect of Corporate Governance Mechanisms on Financial Performance of Insurance Companies in Nigeria. Journal of Finance and Accounting, 5(3), 93-103. https://doi.org/10.12691/jfa-5-3-4

Jeng, V., \& Lai, G. C. (2005). Ownership Structure, Agency Costs, Specialization, and Efficiency: Analysis of Keiretsu and Independent Insurers in the Japanese Nonlife Insurance Industry. Journal of Risk and Insurance, 72(1), 105-158. https://doi.org/10.1111/j.0022-4367.2005.00118.x

Kader, H. A., Adams, M., \& Hardwick, P. (2010). The Cost Efficiency of Takaful Insurance Companies. The Geneva Papers on Risk and Insurance - Issues and Practice, 35(1), 161-181. https://doi.org/10.1057/gpp.2009.33

Kader, H. A., Adams, M., Hardwick, P., \& Kwon, W. J. (2014). Cost efficiency and board composition under different takaful insurance business models. International Review of Financial Analysis, 32, 60-70. https://doi.org/10.1016/j.irfa.2013.12.008

Karbhari, Y., Muye, I., Hassan, A. F. S., \& Elnahass, M. (2018). Governance mechanisms and efficiency: Evidence from an alternative insurance (Takaful) market. Journal of International Financial Markets, Institutions and Money, 56, 71-92. https://doi.org/10.1016/j.intfin.2018.02.017

Lagasio, V. (2018). Corporate governance in banks: Systematic literature review and meta-analysis. Corporate Ownership \& Control, 16(1-1), 113-126. http://doi.org/10.22495/cocv16i1c1art1

Lambalk, S., \& de Graaf, F. J. (2017). Explaining the relationship between firm performance and corporate governance of Dutch non-life insurance companies: Dutch mutual and commercial companies compared. Journal of Sustainable Finance \& Investment, $\quad 7(2), \quad$ 197-231. https://doi.org/10.1080/20430795.2016.1269520

Lamm-Tennant, J., \& Starks, L. T. (1993). Stock Versus Mutual Ownership Structures: The Risk Implications. The Journal of Business, 66(1), 29-46. http://dx.doi.org/10.1086/296592

Lee, H. S., Cheng, F. F., Har, W. M., Md Nassir, A., \& Ab Razak, N. H. (2019). Efficiency, firm-specific and corporate governance factors of the Takaful insurance. International Journal of Islamic and Middle Eastern Finance and Management. https://doi.org/10.1108/IMEFM-06-2018-0187

Li, H., Zhang, H., Tsai, S. B., \& Qiu, A. (2017). China's Insurance Regulatory Reform, Corporate Governance Behavior and Insurers' Governance Effectiveness. International Journal of Environmental Research and Public Health, 14(10). https://doi.org/10.3390/ijerph14101238

Lin, S., Pope, P. F., \& Young, S. (2003). Stock Market Reaction to the Appointment of Outside Directors. Journal of Business Finance Accounting, 30(3-4), 351-382. https://doi.org/10.1111/1468-5957.t01-1-00001

Locatelli, R., Schena, C., Tanda, A., \& Uselli, A. (2018). La relazione tra diversità e competenza dei board e performance delle banche. Bancaria, 8, 44-59.

MacMinn, R. D., \& Ren, Y. (2010). Mutual Versus Stock Insurers: A Synthesis of Theory and Empirical Work. SSRN Electronic Journal. https://doi.org/10.2139/ssrn.1697779

Magee, S., Schilling, C., \& Sheedy, E. (2019). Risk governance in the insurance sector-determinants and consequences in an international sample. Journal of Risk and Insurance, 86(2), 381-413. https://doi.org/10.1111/jori.12218

Markonah, M., Sudiro, A., \& Rahayu, M. (2019). The Effect of Corporate Governance and Premium Growth on the Performance of Insurance Companies in Indonesia. European Research Studies Journal, XXII(2), 367-383. Retrieved from https://www.ersj.eu/journal/1450/download

Marx, L. M., Mayers, D., \& Smith, C. W. (2001). Insurer Ownership Structure and Executive Compensation as Complements. The Journal of Risk and Insurance, 68(3), 449. https://doi.org/10.2307/2678118 
Mayers, D., \& Smith, C. W. (1981). Contractual Provisions, Organizational Structure, and Conflict Control in Insurance Markets. The Journal of Business, 54(3), 407-434. https://doi.org/10.1086/296138

Mayers, D., \& Smith, C. W. (1988). Ownership Structure across Lines of Property-Casualty Insurance. The Journal of Law \& Economics, 31(2), 351-378. https://doi.org/10.1086/467160

Mayers, D., \& Smith, C. W. (1992). Executive Compensation in the Life Insurance Industry. The Journal of Business, 65(1), 51-74. https://doi.org/10.1086/296557

Mayers, D., \& Smith, C. W. (1994). Managerial Discretion, Regulation, and Stock Insurer Ownership Structure. The Journal of Risk and Insurance, 61(4), 638. https://doi.org/10.2307/253642

Mayers, D., \& Smith, C. W. (2010). Compensation and Board Structure: Evidence From the Insurance Industry. Journal of Risk and Insurance, 77(2), 297-327. https://doi.org/10.1111/j.1539-6975.2010.01352.x

Mayers, D., Shivdasani, A., \& Smith, C. W. (1997). Board composition and corporate control: Evidence from the insurance industry. The Journal of Business, 70(1), 33-62. https://doi.org/10.1086/209707

Miller, S. M. (2011). Managerial Discretion and Corporate Governance in Publicly Traded Firms: Evidence From the Property-Liability Insurance Industry. Journal of Risk and Insurance, 731-760. https://doi.org/10.1111/j.1539-6975.2011.01415.x

Miller, S., \& Yang, T. (2015). Board Leadership Structure of Publicly traded Insurance Companies. Journal of Insurance Issues, 38(2), 184-232. http://dx.doi.org/10.2139/ssrn.2641417

Najjar, N. J., \& Salman, R. A. M. (2013). The Impact of Corporate Governance on the Insurance Firm's Performance in Bahrain. International Journal of Learning and Development, 3(2). https://doi.org/10.5296/ijld.v3i2.3511

Ng, T., Chong, L., \& Ismail, H. (2012). Is the risk management committee only a procedural compliance?: An insight into managing risk taking among insurance companies in Malaysia. The Journal of Risk Finance, 14(1), 71-86. https://doi.org/10.1108/15265941311288112

O’Sullivan, N., \& Diacon, S. R. (1999). Internal and External Governance Mechanisms: Evidence from the UK insurance industry. Corporate Governance, 7(4), 363-373. https://doi.org/10.1111/1467-8683.00166

O’Sullivan, N., \& Diacon, S. R. (2003). Board Composition and Performance in Life Insurance Companies. British Journal of Management, 14(2), 115-129. https://doi.org/10.1111/1467-8551.00269

Pavić Kramarić, T., Aleksic, A., \& Pejic-Bach, M. (2018). Measuring the impact of board characteristics on the performance of Croatian insurance companies. International Journal of Engineering Business Management, 10. https://doi.org/10.1177/1847979018765864

Pottier, S. W., \& Sommer, D. W. (1997). Agency Theory and Life Insurer Ownership Structure. The Journal of Risk and Insurance, 64(3), 529. https://doi.org/10.2307/253763

Pullano, L. (2011). Un'indagine empirica sulla governance delle imprese di assicurazioni quotate. Economia Aziendale Online, 2(2/2011), 189-207. https://doi.org/10.13132/2038-5498/2.2.189-207

Rosenbusch, N., Brinckmann, J., \& Muller, V. (2013). Does acquiring venture capital pay off for the funded firms? A meta-analysis on the relationship between venture capital investment and funded firm financial performance. Journal of Business Venturing, 28(3), 335-353. https://doi.org/10.1016/j.jbusvent.2012.04.002

Sandada, M., Manzanga, N., \& Shamhuyenhanzva, R. (2015). How Do Board Characteristics Influence Business Performance? Evidence from Non-life Insurance Firms in Zimbabwe. Acta Universitatis Danubius. Economica, 11(4), 103-116. Retrieved from http://journals.univ-danubius.ro/index.php/oeconomica/article/view/2853/2837

Tanda, A., \& Manzi, G. (2019). Underpricing of venture backed IPOs: a meta-analysis approach. Economics of Innovation and New Technology. https://doi.org/10.1080/10438599.2019.1625154

Venuti, F., \& Alfiero, S. (2016). The Impact of Corporate Governance on Risk Taking in European Insurance Industry. World Academy of Science, Engineering And Technology, 10(1), 190-194. Retrieved from http://hdl.handle.net/2318/1558641.

Wang, J. L., Jeng, V., \& Peng, J. L. (2007). The Impact of Corporate Governance Structure on the Efficiency Performance of Insurance Companies in Taiwan. The Geneva Papers on Risk and Insurance. Issues and Practice, 32(2), 264-282. https://doi.org/10.1057/palgrave.gpp.2510125

Wu, Y. C., Kweh, Q. L., Lu, W. M., \& Azizan, N. A. (2016). The impacts of risk-management committee 
characteristics and prestige on efficiency. Journal of the Operational Research Society, 67(6), 813-829. https://doi.org/10.1057/jors.2015.101

\section{Notes}

Note 1. It differs from the committee of controllers in the traditional Italian governance model, because here outside directors can be part of the Audit Committee (Adams \& Jiang, 2016; Hardwick et al., 2011; I et al., 2009), although some tasks coincide.

Note 2. To this end, we employed the Vosviewer software to build clusters of publications, authors or journals and to display two-dimensional maps of the chosen relationships.

Note 3. No criteria of inclusion have been placed with reference to the time horizon (in fact the time horizon dates back to 1995), nor to the geographical scope of reference, as both profiles are worth considering.

Note 4. To be included in the meta analysis, it was not necessary for the paper to focus exclusively on that relationship, but it was essential that the relationship was included in the analysis.

Note 5. This choice is also motivated by the level of heterogeneity between studies. In fact, the level of heterogeneity among studies for the variable "size" is approximately 0.74 as measured by statistics I2. The value of I 2 varies between 0 and 1 and indicates the degree of heterogeneity between the samples included in the meta-analysis. The higher the value of this measure, the greater the heterogeneity (Harris, Bradburn, Deeks, Harbord, Altman, \& Sterne, 2008; Higgins \& Thompson, 2004). In our case, 0.74 of the variability in the results is attributable to differences in the sample and study approach. This measure is slightly higher (it is about 0.807) for the variable "percentage of Independent directors".

\section{Copyrights}

Copyright for this article is retained by the author(s), with first publication rights granted to the journal.

This is an open-access article distributed under the terms and conditions of the Creative Commons Attribution license (http://creativecommons.org/licenses/by/4.0/). 